\title{
ІОНІЗАЦІЯ ТА ЗБУДЖЕННЯ МОЛЕКУЛ УРАЦИЛУ ЕЛЕКТРОННИМ УДАРОМ
}

\author{
M.I. СУХОВІЯ, М.I. ШАФРАНЬОШ, М.М. ЧАВАРГА, І.І. ШАФРАНЬОШ
}

УДК 535.37:547.672

(Вул. Волошина, 54, Ужгород 88000; e-mail: ivanshafr@gmail.com)

\begin{abstract}
Експериментальним шляхом отримано дані про абсолютні величини перерізів утворення позитивних і негативних іонів азотистої основи нуклеїнових кислот - урацилу. Показано, що максимальних значень переріз утворення негативних іонів досягає при енергї бомбардуючих електронів $1,1 \mathrm{eB}$, і його абсолютна величина становить $5,0 \cdot 10^{-18} \mathrm{~cm}^{2}$. Визначено абсолютну величину та енергетичну залежність перерізу утворення позитивних іонів для урацилу в інтервалі енергій електронів від порога до 200 еВ. Максимум перерізу іонізації знаходиться при енергії 95 еВ і дорівнює $(1,0 \pm 0,1) \cdot 10^{-15} \mathrm{~cm}^{2}$. Отримано спектри люмінесценції ізольованих молекул урацилу в області довжин хвиль 200-500 нм під дією повільних електронів. У спектрі спостерігаються близько 20 спектральних смуг і ліній. Показано, що спектр випромінювання урацилу формують процеси дисоціативного збудження молекул, дисоціативного збудження з іонізацією, збудження електронних рівнів вихідної молекули та молекулярного іона. Обговорено біофізичні наслідки отриманих результатів.
\end{abstract}

\section{1. Вступ}

Перші дослідження взаємодії повільних моноенергетичних електронів з молекулами азотистих основ нуклеїнових кислот розпочаті авторами даної статті ще у 80-х роках минулого століття [1]. У подальших наших експериментах [2,3] були реалізовані нові методичні розробки з формування газової фази молекул без помітної деградації їх структур. Зокрема, було отримано інтенсивні молекулярні пучки. Це дозволило виявити, що внаслідок електронного удару в біомолекулах протікають різні фізичні процеси: збудження, іонізація, дисоціативне збудження та дисоціативна іонізація, оцінено ймовірності кожного із процесів при різних енергіях електронів.

Експериментальне вивчення процесів непружних взаємодій біомолекул з повільними електронами зумовлене, в першу чергу, важливістю проблеми внутріклітинного опромінення біоструктур вторинними електронами, які утворюються у значній кількості в речовині при дії випромінювання різних видів. У зв'язку з цим стає актуальним фізичне моделюва- ння клітинних іонізаційних процесів умовами лабораторного експерименту, за яких можна забезпечити моноенергетичність та однократність електронних впливів на біоструктури у достатньо широкому діапазоні енергій. Інформація про фізичну структуру молекул необхідна для розуміння ролі первинних фізичних процесів у забезпеченні функціювання біосистем та впливу на них різних чинників навколишнього середовища. Серед цих чинників особлива увага відводиться природній та штучній радіації. Взаємодія високоенергетичної радіації з живими клітинами, в основному, не призводить прямо до деградації біополімерних молекул, зокрема, до розривів ковалентних зв'язків у первинній структурі нуклеїнових кислот. Цю функцію виконують вторинні електрони, які утворюються у значній кількості $\left(4 \cdot 10^{4}\right.$ електронів на $1 \mathrm{MeB}$ налітаючої високоенергетичної частинки) у біоречовині [4]. Більшість вторинних електронів є низькоенергетичними (повільними) з енергіями від долей до десятків еВ [4]. Саме з повільними електронами пов'язують, на сьогодні, основну частину деструктивних змін на молекулярному рівні біоструктур. При цьому головною мішенню стають генетичні макромолекули ДНК і РНК.

У попередніх дослідженнях [5-7] ми вивчали процеси іонізації та збудження молекул основ нуклеїнових кислот цитозину і тиміну у газовій фазі повільними електронами. Дане дослідження присвячене урацилу.

\section{2. Експериментальні установки та методики досліджень}

\section{1. Іонізачія}

Основою експерименту є методика пучків електронів та молекул, що перетинаються, яка була успішно застосована раніше [5]. Пучок молекул урацилу (див. рис. 1) отримується за допомогою термічного ефузійного джерела багатоканального типу та системи колімуючих щілин. Складовими частинами ефузійного джерела є: мідний контейнер з препаратом урацилу, резистивний нагрівник контейнера, прокалібрований 


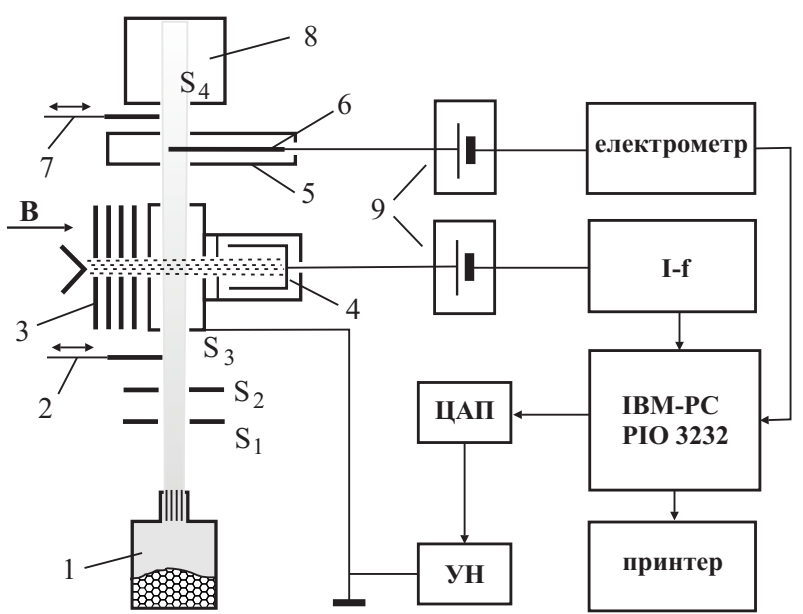

Рис. 1. Блок-схема експерименту для дослідження іонізації молекул урацилу: 1 - тигель; S1-S4 - колімуючі щілини; 2, 7 засувки молекулярного пучка; 3 - електронна гармата; 4 - колектор електронів; 5 - колектор іонів; 6 - зонд; 8 - колектор молекул; 9 - гальванічні джерела напруги; I-f - перетворювач струм-частота; ЦАП - цифро-аналоговий перетворювач; УН підсилювач напруги

термопарний (хромель-алюмель) датчик температури контейнера, теплові екрани. Сам контейнер було виконано у вигляді порожнистого циліндра, на одному 3 кінців якого монтувався елемент із ефузійними каналами (100 каналів на площі 1,5 × 1,5 мм²), а на протилежному - герметична закривка. На ній розміщався препарат урацилу (фірма Sigma-Aldrich, чистота 99\%) та датчик температури. Конструкція нагрівника була такою, що температура елемента з мікроканалами була на $10{ }^{\circ} \mathrm{C}$ вищою від температури закривки $\left(93^{\circ} \mathrm{C}\right)$. Таким чином не допускалося закупорення мікроканалів під час експерименту. Молекули проходили через область взаємодії з електронним пучком і в кінці свого шляху осідали на дні колектоpa, утворюючи з часом помітний слід - конденсат. Сам колектор являв собою мідну камеру циліндричної форми із вхідною щілиною $S_{4}$ та плоским дном і мав температуру рідкого азоту. Вимірювання маси конденсату і часу його утворення давали змогу визначити інтенсивність молекулярного пучка, а відповідно, і його концентрацію.

Джерелом електронів служила п'ятиелектродна гармата із катодом, виготовленим із торованого вольфраму. Температура електронної гармати була на рівні $110^{\circ} \mathrm{C}$, що забезпечувало стабільність параметрів гармати під час роботи. Перший електрод гармати знаходився при невеликому негативному потенціалі, який затримував низькоенергетичну частину потоку електронів із катоду. Електрони пучка, що про-

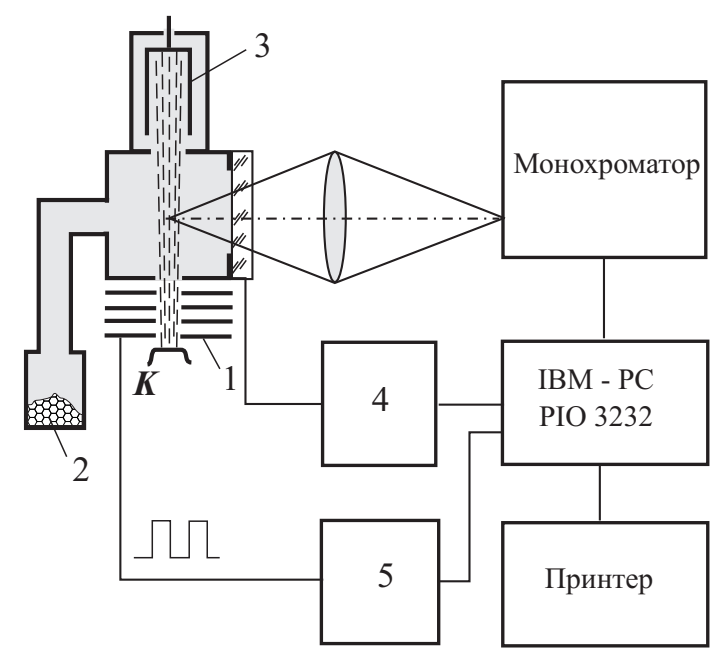

Рис. 2. Блок-схема експерименту для вивчення збудження молекул урацилу: 1 - електронна гармата; $K$ - емітер електронів; 2 - препарат урацилу; 3 - колектор електронів (циліндр Фарадея); 4 - джерело скануючого потенціалу електронного пучка; 5 - блок модуляції електронного пучка

йшли область зіткнень, уловлювалися циліндром Фарадея, який знаходився під додатним потенціалом. Виміри проводилися при силі струму пучка електронів $1 \cdot 10^{-7}-1 \cdot 10^{-6} \mathrm{~A}$ і енергетичній неоднорідності електронів на піввисоті їхнього енергетичного розподілу $\Delta E_{1 / 2} \sim 0,3 \mathrm{eB}$. Електронна гармата розміщалася у поздовжньому полі з індукцією $B=1,2 \cdot 10^{-2}$ Тл. Калібрування енергетичної шкали електронів здійснювалося за резонансним піком утворення іонів $S F_{6}^{-}$, енергетичне положення якого визначало нуль шкали.

Для повного збору іонів, що утворилися в області перетину електронного та молекулярного пучків, на шляху молекулярного пучка встановлюється прохідний колектор, всередині якого міститься осьовий електрод (зонд). Повнота збору іонів забезпечується потенціалом зонда 25 В, полярність якого визначається знаком заряду іонів, що реєструвалися. Магнітне поле унеможливлювало попадання на зонд електронів, розсіяних на молекулах урацилу та поверхнях електродів.

\section{2. Збудження}

Формування газової фази урацилу відбувалося шляхом його нагріву в окремому металевому контейнеpi (рис. 2). Утворена газова фаза урацилу по паропроводу надходила у замкнену кубічну форму (комірку) об'ємом $\sim 2$ см $^{3}$. Температура контейнера 3 порошком урацилу не перевищувала 350 K. На 


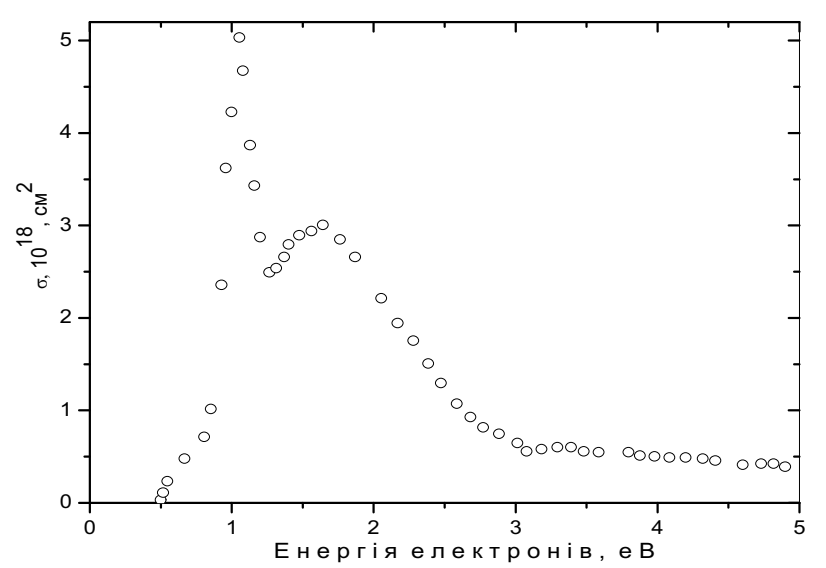

Рис. 3. Залежність абсолютної величини перерізу утворення негативних іонів урацилу від енергії електронів

одній із зовнішніх граней комірки монтувалися діафрагма (діаметр 1,5 мм) для вводу електронного пучка та джерело пучка, а на протилежній - приймач пучка електронів (циліндр Фарадея). Пучок електронів формувався п'ятиелектродною гарматою з вольфрамовим катодом. Комірка поміщалася у магнітне поле так, що його силові лінії були паралельними електронному пучку. Калібрування шкали енергій електронів здійснювалося за значенням енергетичного порога збудження смуги молекулярного азоту з $\lambda=315,9$ нм (електронний перехід $X^{1} \Sigma_{g}^{+}-C^{3} \Pi_{u}$ - друга позитивна система) з похибкою $\pm 0,25 \mathrm{eB}$. Індукція магнітного поля становила $\sim 1,2 \cdot 10^{-2}$ Тл. Для виведення випромінювання із комірки на їі грані було змонтовано кварцове віконце. Для реєстрації випромінювання був використаний спектрофотометр, який складався із дифракційного монохроматора (МДР-23) з оберненою дисперсією $1 \mathrm{Hм} / \mathrm{Mм}$, фотоелектронного помножувача (ФЕУ106) та системи реєстрації фотоелектронних імпульсів. Для покращення відношення сигнал/шум система реєстрації працювала у режимі рахунку фотоелектронних імпульсів разом з модуляцією електронного пучка [5].

Експерименти проводилися при таких умовах: сила струму пучка електронів знаходилася у межах (3-4)·10 ${ }^{-5}$ А при енергетичній неоднорідності електронів на піввисоті їх енергетичного розподілу $\Delta E_{1 / 2} \sim 0,5 \mathrm{eB} ;$ ступінь вакууму у камері, де розміщалася комірка 3 парами урацилу, становив $\sim 1 \cdot 10^{-5}$ Па. Для уникнення конденсації парів урацилу на віконцях та електродах електронної гармати комірка нагрівалася до температури $370 \mathrm{~K}$.

\section{3. Результати досліджень}

\section{1. Іонізація - негативні іони}

В результаті проведених експериментів було виявлено утворення негативних іонів урацилу при взаємодії його молекул з електронним пучком. Вперше експериментально виміряні абсолютні величини повних ефективних перерізів для негативних іонів урацилу в області енергій електронів від 0,4 до 5 еВ. Отримані результати наведено на рис. 3 , де по осі ординат відкладено переріз іонізації в $\mathrm{cm}^{2}$, а по осі абсцис - енергію бомбардуючих електронів в $\mathrm{eB}$.

Як видно із рис. 3, процес утворення негативних іонів урацилу має резонансний характер з його максимальним проявом при енергї електронів $1,1 \mathrm{eB}$. Окремо слід зупинитися на абсолютній величині перерізу утворення негативних іонів урацилу. Максимальне значення цього перерізу, за нашими вимірами, становить $5 \cdot 10^{-18}$ см$^{2}$. Виміряний ефективний переріз має зміст повного перерізу, тобто включає перерізи утворення негативних іонів як цілої молекули, так і ї̈ фрагментів (так звані парціальні перерізи). Але відповідно до загальних фізичних уявлень, при малих концентраціях взаємодіючих частинок практично неможливе утворення помітних кількостей негативних іонів цілісних молекул. Тому утворений негативний іон цілої молекули, який за законами збереження повинен знаходитися у збудженому стані (електронному чи коливному), буде з найбільшою імовірністю дисоціювати на нейтральний і заряджений фрагменти. В області малих енергій налітаючих електронів, як у нашому випадку, найбільш імовірними незарядженими фрагментами можуть бути атоми водню, які мають найменшу величину енергії зв'язку з піримідиновим кільцем [8]. Таким чином, формування негативних іонів буде протікати двостадійно:

$e+\mathrm{C}_{4} \mathrm{H}_{4} \mathrm{~N}_{2} \mathrm{O}_{2} \rightarrow\left[\left(\mathrm{C}_{4} \mathrm{H}_{4} \mathrm{~N}_{2} \mathrm{O}_{2}\right)^{-}\right]^{*} \rightarrow\left(\mathrm{C}_{4} \mathrm{H}_{3} \mathrm{~N}_{2} \mathrm{O}_{2}\right)^{-}+\mathrm{H}$.

Зауважимо, що наведена у роботі [9] оцінка перерізу утворення негативних іонів урацилу дає на два порядки більші значення. Оскільки, на відміну від [9], у наших дослідженнях безпосередньо визначалась концентрація молекул у молекулярному пучку, а інші деталі методики є надійно апробованими [5], то ми вважаємо оцінні дані роботи [9] завищеними. 


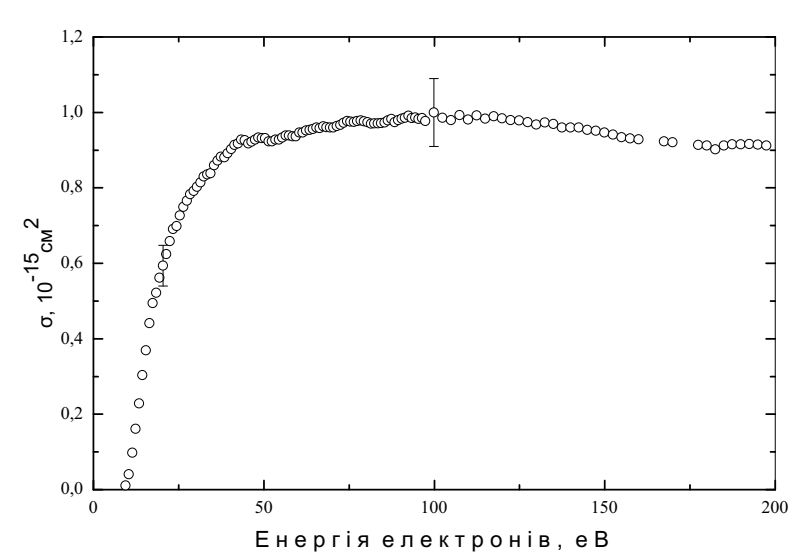

Рис. 4. Залежність абсолютної величини повного перерізу утворення позитивних іонів урацилу від енергії електронів

\section{2. Іонізація - позитивні іони}

У прямому експерименті визначена абсолютна величина перерізу іонізації та ㄲï енергетична залежність (функція іонізації) для урацилу в інтервалі енергій бомбардуючих електронів від порога до 200 еВ. Отримані дані показано на рис.4, де по осі ординат відкладено переріз іонізації в $\mathrm{cm}^{2}$, а по осі абсцис - енергію іонізуючих електронів в електрон-вольтах.

Як видно із рис. 4, функція іонізації молекул урацилу після припорогового росту досить полога зі слабо вираженими особливостями та з широким плато. Зокрема, максимум перерізу іонізації урацилу знаходиться при енергії 95 еВ і дорівнює $(1,0 \pm 0,1) \times$ $10^{-15} \mathrm{~cm}^{2}$. Визначений поріг утворення позитивних іонів для урацилу $-9,4 \pm 0,2 \mathrm{eB}$, що непогано узгоджується 3 даними, отриманими іншими методами [10]. Переріз утворення позитивних іонів також має зміст повного перерізу, тобто складається з перерізів утворення іонів як вихідної молекули, так і ㄲï фрагментів (парціальних перерізів). На кривій іонізації помітна структура у вигляді зламів, яка зумовлена, на нашу думку, внесками від процесів утворення молекулярних іонів у збуджених станах та дисоціативної іонізації. Підставою для такого твердження служать значні перерізи дисоціативної іонізації досліджуваних молекул (див. нижче).

\section{3. Мас-спектри молекул урацилу}

Результати мас-спектрометричного дослідження урацилу (фрагментного складу) при енергії бомбардуючих електронів $95 \mathrm{eB}$ наведено на рис. 5, де по осі абсцис показано відношення маси іона до його заряду в системі атомних одиниць, а по осі ординат -

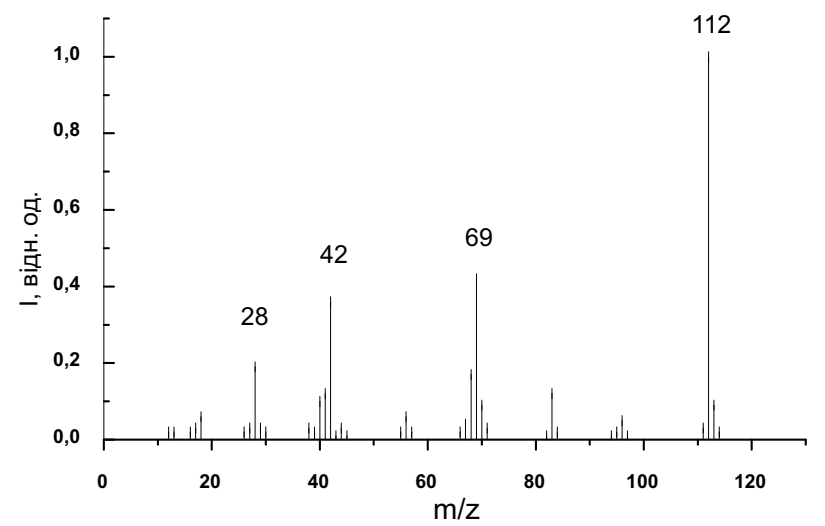

Рис. 5. Мас-спектр молекул урацилу

інтенсивність утворених іонів у довільних одиницях. Характерними ознаками приведеного мас-спектра є: присутність найбільш інтенсивної лінії, яка відповідає однозарядному молекулярному іону урацилу (лінія $m / z 112$ ); наявність великої кількості ліній різної інтенсивності, які відносяться до новоутворених іонних фрагментів; відсутність ліній двозарядних молекулярних іонів, а також іонів димерних та тримерних молекулярних сполук. Ідентифікація ліній у масспектрах проводилася шляхом встановлення їх відповідності масам можливих фрагментів, а також виходячи з можливих схем фрагментації. При цьому були враховані відомі положення та закономірності масспектрометрії складних молекул $[11,12]$.

Особливої уваги заслуговує порівняння отриманих нами мас-спектрів із результатами досліджень інших авторів. У табл. 1 наведено відносні інтенсивності деяких мас-спектральних ліній урацилу, які взяті з різних джерел $[13,14]$. При цьому зазначимо, що енергії бомбардуючих електронів $(E)$, при яких були зняті мас-спектри, дещо відрізнялися. Однак це неістотно впливає на відносні інтенсивності наведених масспектральних ліній, оскільки енергетичні залежності парціальних перерізів іонізації в області 75-120 еВ є подібними [15].

Із табл. 1 випливає, що результати наших досліджень, в межах похибок вимірів, збігаються з результатами [13] і відрізняються від даних [14]. Пояснення таким фактам ми бачимо в тому, що температури робочої речовини (для отримання газової фази урацилу) у наших дослідженнях і у [14] помітно відрізнялися. Так, температура робочої речовини становила: у нашому дослідженні та в роботі [13] $380 \mathrm{~K}$, а в [14] - 423 К. Звідси можна зробити висновок про те, що, починаючи з температур $400 \mathrm{~K}$, у молекулах урацилу проходить помітна термічна фрагментація. Зокрема, 


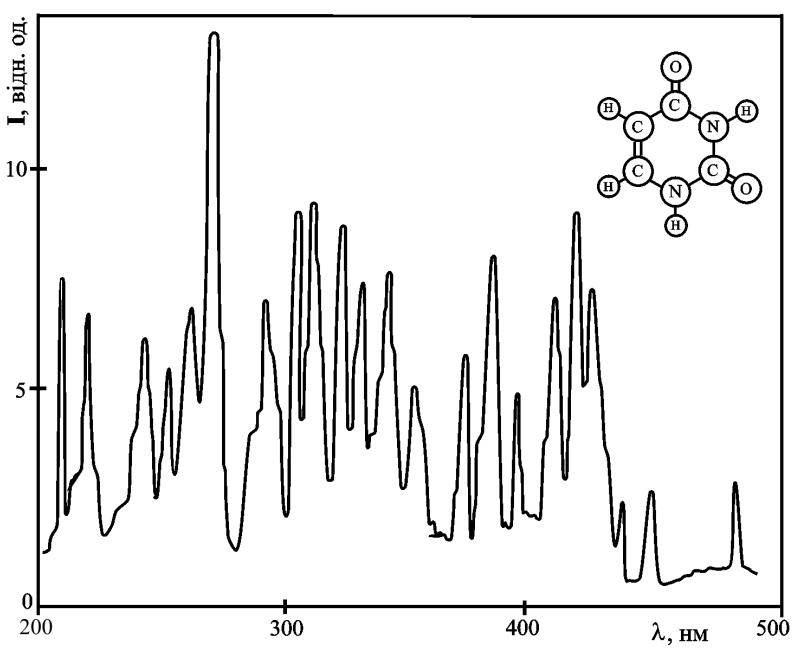

Рис. 6. Спектр люмінесценції молекул урацилу при енергї електронів $100 \mathrm{eB}$

їі прояв спостерігається у зменшенні відносних інтенсивностей мас-спектральних ліній, які відповідають молекулярним іонам. Якраз, це і характерно для результатів досліджень [14].

Отримані дані про повний переріз іонізації молекул урацилу та їх мас-спектр дали можливість визначити парціальні перерізи утворення іонів найбільш ймовірних фрагментів молекул урацилу при енергії бомбардуючих електронів 95 еВ (див. табл. 2, де $m / z$ - маса молекулярного фрагмента в атомних одиницях маси; $\sigma-$ величини перерізів утворення іонних фрагментів молекул).

Доречним буде порівняння абсолютних величин перерізів утворення позитивних іонів, визначених у наших дослідженнях і в роботі [13]. Із табл. 3 видно, що перерізи відрізняються майже у два рази. Таку розбіжність можна пояснити тим, що результати експерименту [13] були пронормовані на теоретичні розрахунки, виконані у рамках напівкласичного форма-

Т а б л и ц я 1. Відносні інтенсивності масспектральних ліній урацилу

\begin{tabular}{c|c|c|c|c}
\hline \multirow{2}{*}{$m / z$} & \multirow{2}{*}{ Іон } & \multicolumn{3}{|c}{ Інтенсивність, відн. од. } \\
\cline { 3 - 5 } & & $\begin{array}{c}{[14]} \\
E=75 \mathrm{eB}\end{array}$ & $\begin{array}{c}{[13]} \\
E=120 \mathrm{eB}\end{array}$ & $\begin{array}{c}\text { Дане досл. } \\
E=95 \mathrm{eB}\end{array}$ \\
\hline 112 & $\mathrm{C}_{4} \mathrm{H}_{4} \mathrm{~N}_{2} \mathrm{O}_{2}^{+}$ & 1 & 1 & 1 \\
69 & $\mathrm{C}_{3} \mathrm{H}_{3} \mathrm{NO}^{+}$ & 0,52 & 0,4 & 0,42 \\
42 & $\mathrm{CNO}^{+} ; \mathrm{C}_{2} \mathrm{H}_{2} \mathrm{O}^{+} ;$ & 0,44 & 0,3 & 0,37 \\
& $\mathrm{CH}_{2} \mathrm{~N}_{2}^{+}$ & & & \\
41 & $\mathrm{CHN}_{2}^{+} ; \mathrm{C}_{2} \mathrm{H}_{3} \mathrm{~N}^{+}$ & 0,26 & 0,13 & 0,13 \\
40 & $\mathrm{C}_{2} \mathrm{H}_{2} \mathrm{~N}^{+} ; \mathrm{CN}_{2}^{+}$ & 0,28 & 0,11 & 0,11 \\
28 & $\mathrm{CO}^{+}$ & 0,26 & 0,19 & 0,2 \\
\hline
\end{tabular}

лізму Дойча-Мерка [16, 17], в основі якого лежить наближення Бете [18]. Таким чином, по суті табл. 3 відображає рівень узгодженості наших і розрахункових даних. Загальновідомо [19], що наближення Бете дає завищені величини перерізів зіткнень в області малих енергій.

\section{4. Збудження}

У роботі експериментально отримані спектри фотоемісії (люмінесценції) урацилу під дією електронного удару в області довжин хвиль 200-500 нм для різних енергій бомбардуючих електронів. На рис. 6 наведено фотоемісійний спектр урацилу при енергії електронів 100 еВ. У спектрі чітко проявляються молекулярні смуги, максимуми яких знаходяться при таких довжинах хвиль $\lambda_{M}: 205,5 ; 218,5 ; 241,9 ; 254,0 ; 265,3$; 277,$4 ; 297,2 ; 310,0 ; 317,1 ; 328,4 ; 333,5 ; 344,5 ; 357,3$; 377,$1 ; 387,9 ; 398,0 ; 412,3 ; 421,0 ; 427,3 ; 451,1 ; 486,1$. Як видно із рис.6, практично всі смуги мають складний характер, що свідчить про їх суперпозиційну природу. Для порівняння тут зазначимо, що при фотозбудженні полікристалічних плівок урацилу спектр його люмінесценції являє собою плавну широку смугу в діапазоні довжин хвиль від $\sim 300 \mathrm{нм}$ до $\sim 550 \mathrm{Hм}$ $[20,21]$.

Здійснити повну коректну ідентифікацію спектральних смуг, використовуючи наявну базу літературних даних, досить складно. Однак, незважаючи на це, нам вдалося провести наступний аналіз природи походження смуг в отриманому спектрі. Для цієї мети було використано наведені вище результати мас-спектрометричних досліджень урацилу, дані про ефективні перерізи повної та дисоціативної іонізації

Т а б ли ц я 2. Абсолютні величини перерізів утворення позитивних іонів молекул урацилу та їх фрагментів при енергії електронів 95 еВ

\begin{tabular}{ccc}
\hline$m / z$ & $\mathrm{IoH}$ & $\sigma, 10^{-16} \mathrm{~cm}^{2}$ \\
\hline 112 & $\mathrm{C}_{4} \mathrm{H}_{4} \mathrm{~N}_{2} \mathrm{O}_{2}^{+}$ & 2,69 \\
96 & $\mathrm{C}_{4} \mathrm{H}_{4} \mathrm{~N}_{2} \mathrm{O}^{+}$ & 0,14 \\
83 & $\mathrm{C}_{3} \mathrm{H}_{3} \mathrm{~N}_{2} \mathrm{O}^{+}$ & 0,34 \\
70 & $\mathrm{C}_{3} \mathrm{H}_{4} \mathrm{NO}^{+}$ & 0,28 \\
69 & $\mathrm{C}_{3} \mathrm{H}_{3} \mathrm{NO}^{+}$ & 1,14 \\
68 & $\mathrm{C}_{3} \mathrm{H}_{2} \mathrm{NO}^{+} ; \mathrm{C}_{4} \mathrm{H}_{4} \mathrm{O}^{+}$ & 0,59 \\
56 & $\mathrm{C}_{2} \mathrm{H}_{2} \mathrm{NO}^{+} ; \mathrm{C}_{3} \mathrm{H}_{4} \mathrm{O}^{+}$ & 0,18 \\
42 & $\mathrm{CNO}^{+} ; \mathrm{C}_{2} \mathrm{H}_{2} \mathrm{O}^{+} ; \mathrm{CH}_{2} \mathrm{~N}_{2}^{+}$ & 0,99 \\
41 & $\mathrm{CHN}_{2}^{+} ; \mathrm{C}_{2} \mathrm{H}_{3} \mathrm{~N}^{+}$ & 0,34 \\
40 & $\mathrm{C}_{2} \mathrm{H}_{2} \mathrm{~N}^{+} ; \mathrm{N}_{2}^{+}$ & 0,30 \\
28 & $\mathrm{CO}^{+}$ & 0,53 \\
18 & $\mathrm{H}_{2} \mathrm{O}^{+}$ & 0,20 \\
\hline
\end{tabular}


урацилу електронним ударом, проаналізовано фотоемісійні спектри відповідних хімічних сполук [21, 2225]. Також нами було розраховано рівні електронного збудження молекули урацилу.

Дані табл. 3 свідчать про високу ймовірність фрагментації молекули урацилу під дією електронного удару. Очевидно, що частина заряджених фрагментів буде знаходитися у збуджених станах. При цьому, в першу чергу, слід звернути увагу на ті фрагменти, парціальні перерізи утворення яких найбільші. Це молекулярний іон $-\mathrm{C}_{4} \mathrm{H}_{4} \mathrm{~N}_{2} \mathrm{O}_{2}^{+}$та фрагменти $\mathrm{CO}^{+}, \mathrm{CNO}, \mathrm{C}_{3} \mathrm{H}_{3} \mathrm{NO}^{+}, \mathrm{C}_{3} \mathrm{H}_{2} \mathrm{NO}^{+} ; \mathrm{C}_{4} \mathrm{H}_{4} \mathrm{O}^{+}$. Крім цього, схема фрагментації урацилу передбачає утворення і нейтральних фрагментів, які також можуть перебувати у збуджених станах (дисоціативне збудження). Насамперед, це фрагменти - СО (при розпаді іона $\mathrm{C}_{3} \mathrm{H}_{3} \mathrm{NO}^{+}$), $\mathrm{HNCO}, \mathrm{C}_{3} \mathrm{H}_{3} \mathrm{NO}$ (при розпаді молекулярного іона $-\mathrm{C}_{4} \mathrm{H}_{4} \mathrm{~N}_{2} \mathrm{O}_{2}^{+}$), та $\mathrm{H}$ (при розпаді іона $\mathrm{CHNO}^{+}$). Радіаційний розпад збуджених станів заряджених і нейтральних фрагментів певним чином проявиться в емісійному спектрі урацилу.

Так, смуга 3 максимумом при довжині хвилі $\lambda=$ 205,5 нм, очевидно, є суперпозицією кількох емісійних ліній, які належать іону $\mathrm{CO}^{+}$(перша негативна система, електронний перехід $B^{2} \Sigma^{+} \rightarrow X^{2} \Sigma^{+}$, $\lambda_{M}=206,8 ; 206,1 ; 204,2$ нм). Смуга з максимумом при $\lambda=218,5$ нм є суперпозицією кількох емісій: молекули СО (четверта позитивна, перехід $A^{1} \Pi \rightarrow$ $X^{1} \Sigma^{+}, \lambda=217$ нм) та іона $\mathrm{CO}^{+}$(перша негативна система, електронний перехід $B^{2} \Sigma^{+} \rightarrow X^{2} \Sigma^{+}, \lambda=219$ нм). Смуга з максимумом при $\lambda=241,9$ нм належить $\mathrm{CO}^{+}$(перша негативна система, електронний перехід $B^{2} \Sigma^{+} \rightarrow X^{2} \Sigma^{+}, \lambda=241,9$ нм). У смугах із максимумами при довжинах хвиль $\lambda=256,4$ нм та $\lambda=297,2$ нм присутні лінії нейтрального фрагмента СО (третя позитивна система, перехід $A^{1} \Pi \rightarrow X^{1} \Sigma^{+}, \lambda=256,2$ нм; 297, 3 нм). Смуга з максимумом при $\lambda=265,3$ нм, очевидно, є суперпозицією двох емісійних ліній іона $\mathrm{CO}^{+}$(перша негативна система, електронний перехід $B^{2} \Sigma^{+} \rightarrow X^{2} \Sigma^{+}, \lambda_{M}=267,2 ; 263,9$ нм$)$.

Окремої уваги заслуговує найбільш інтенсивна у спектрі смуга із максимумом при довжині хвилі $\lambda=$ 275 нм. На нашу думку, їі поява пов'язана з раді-

Т а б л и ц я 3. Абсолютні величини перерізів утворення позитивних іонів молекул урацилу при енергії електронів $95 \mathrm{eB}$ в одиницях $10^{-16} \mathrm{~cm}^{2}$

\begin{tabular}{cc|ccc}
\hline$m / z$ & Іон & Дана робота & [13] Виміри \\
\hline 112 & $\mathrm{C}_{4} \mathrm{H}_{4} \mathrm{~N}_{2} \mathrm{O}_{2}^{+}$ & 2,7 & 4,5 \\
69 & $\mathrm{C}_{3} \mathrm{H}_{3} \mathrm{~N}_{O}^{+}$ & 1,1 & 2,3 \\
42 & $\mathrm{CNO}^{+} \mathrm{C}_{2} \mathrm{H}_{2} \mathrm{O}^{+} ; \mathrm{CH}_{2} \mathrm{~N}_{2}^{+}$ & 1,0 & 2,0 \\
\hline
\end{tabular}

аційним розпадом першого збудженого електронноколивного стану молекулярного іона урацилу в його основний стан. Підтвердженням цьому є такі фактори. По-перше, як показує табл. 1, переріз утворення молекулярних іонів є найбільшим. Логічно буде очікувати, що і перерізи утворення молекулярних іонів у збуджених станах, насамперед найнижчих, будуть більшими за перерізи утворення інших заряджених фрагментів у збуджених станах. Цей фактор пояснює найбільшу інтенсивність у спектрі смуги із максимумом при довжині хвилі $\lambda=275$ нм. По-друге, у фотоелектронному спектрі при фотоіонізації урацилу, який наведений у роботі [25], виявлений інтенсивний пік при енергї 14 еВ. Якщо скласти енергію спектрального переходу (для $\lambda=275$ нм) та енергію іонізації урацилу, яка становить $9,4 \pm 0,2 \mathrm{eB}$, то отримаємо значення $\sim 13,9 \mathrm{eB}$, яке практично збігається із енергетичним положенням піка у фотоелектронному спектрі. Таким чином, можна припустити, що у молекулярного іона урацилу існує збуджений електронно-коливний стан при енергії 13,9 еВ, 3 якого можливий радіаційний перехід в основний стан іона.

Як видно з рис. 6, в області довжин хвиль 300-440 нм спостерігаються дві широкі молекулярні смуги, які частково перекриваються і які є підкладкою (фоном) для більш вузьких смуг. Першу з цих смуг ми ототожнюємо з випромінюванням синглетного стану молекули урацилу, а другу - триплетного стану цієї ж молекули. Така інтерпретація не суперечить нашим розрахункам, які були виконані за допомогою напівемпіричного методу AM1 пакета програм HyperChem 8,0. Зазначимо, що при фотозбудженні полікристалічних плівок урацилу на широкій смузі його люмінесценції проявляються два максимуми при довжинах хвиль $\sim 350$ нм та $\sim 420$ нм $[20,21]$.

Спектральна смуга з $\lambda=317,1$ нм (див. 6) може випромінюватися піримідиновим кільцем (переходи $A$ $X)$. У формування смуги $3 \lambda=328,4$ нм роблять внески випромінювання фрагментів $\mathrm{CN}^{+}$(переходи $\left.C^{1} \Sigma-A^{1} \Sigma\right)$ та NCN ((переходи $\left.{ }^{3} \Pi_{u}-{ }^{3} \Sigma_{g}\right)$. Смугу 3 максимумом при $\lambda=333,5$ нм випромінюе NCN група $\left({ }^{3} \Pi_{u}-{ }^{3} \Sigma_{g}-\right.$ перехід), а смуги з максимумами при $\lambda=344,5$ нм; 357,3 нм належать групі HNCN (переходи $A-X)$. При $\lambda=377,1$ нм і $\lambda=388,3$ нм проявляється випромінювання нейтрального фрагмента СО кометної системи (379,6 нм) та системи Герцберга (389,3 нм). У формуванні смуги $\lambda=411,5$ нм беруть участь фрагменти СО (переходи у системі Герцберга, 412,5) та водень ( $\mathrm{H}_{\delta} 410,1$ нм). Інтенсивна лінія при $\lambda=421,0$ нм належить фрагменту $\mathrm{CH}^{+}$(перехід 
$A-X, \lambda=421,0$ нм). Випромінювання нейтрального фрагмента СО проявляється у смузі з довжиною хвилі 427,3 нм (кометна система $\lambda=427,3$ нм), а також у смузі з довжиною хвилі 451,1 нм (система Ангстрема $\lambda=451,0$ нм). Збудження вищеназваних смуг СО та $\mathrm{CO}^{+}$електронним ударом детально вивчалися у роботі [25]. В окремих смугах спектра можливий внесок спектральних ліній атома водню серії Бальмера. Зокрема, це смуги з максимумами при $\lambda=398,4$ нм $\left(\mathrm{H}_{\varepsilon}=397,07 \mathrm{Hм}\right) ; \lambda=412,3 \mathrm{Hм}\left(\mathrm{H}_{\delta}=410,1 \mathrm{Hм}\right) ;$ $\lambda=427,3 \mathrm{Hм}\left(\mathrm{H}_{\gamma}=434,05 \mathrm{Hм}\right)$. Особливо чітко спостерігається випромінювання лініі $\mathrm{H}_{\beta}$ атома водню при $\lambda=486,1$ нм.

\section{4. Обговорення результатів}

Насамперед хочемо зауважити, що ці результати отримані нами для молекулярного об'єкта, який має виняткове біологічне значення. Урацил, разом 3 іншими азотистими основами - тиміном, аденіном, цитозином та гуаніном - $є$ важливою складовою генетичних макромолекул нуклеїнових кислот.

Схематично сукупність основних фізичних процесів з участю молекули М у непружних взаємодіях з електроном $e$ можна зобразити таким чином:

$$
\begin{array}{ll}
M+e \rightarrow M^{*}+e & \text { (збудження молекули) }, \\
M+e \rightarrow M^{+}+2 e & \text { (утворення позитивного } \\
& \text { іона молекули), } \\
M+e \rightarrow M^{-} & \text {(утворення негативного } \\
& \text { іона молекули), } \\
M+e \rightarrow M_{1}^{*}+M_{2}+e & \text { (дисоціативне збудження) } \\
M+e \rightarrow M_{1}^{+}+M_{2}+2 e & \text { (дисоціація з утворенням } \\
& \text { позитивних іонів), } \\
M+e \rightarrow M_{1}^{-}+M_{2} & \text { (дисоціативна іонізація з } \\
& \text { утворенням негативних } \\
& \text { іонів), } \\
M+e \rightarrow M_{1}^{+}+M_{2}^{-}+e & \text { (диполярна дисоціація). }
\end{array}
$$

Можливі й інші перетворення. Наприклад, крім збуджених та іонізованих продуктів, можуть формуватися також нейтральні фрагменти, які досить важко ідентифікувати. Відзначимо, що вищенаведені процеси протікають практично одночасно, з великими швидкостями і з різними ймовірностями. Таким чином, пояснюючи конкретні експериментальні результати, необхідно враховувати внесок багатьох каналів.

Слід також мати на увазі, що в результаті непружних взаємодій повільних електронів із молекулами можливе (на відміну від фотопроцесів) пряме збудження метастабільних триплетних станів. Можна припустити, що саме через такі довгоживучі збуджені стани створюються умови для резонансного формування негативних іонів. Пряме утворення триплетних збуджених станів молекул цитозину і тиміну показане в наших попередніх роботах, наприклад, у [2] і [7] відповідно. Для більш повної інтерпретації отриманих даних для урацилу доцільно експериментально дослідити функції збудження відповідних спектральних смуг та їх енергетичні пороги. Такі завдання є у планах подальших досліджень.

Відкритим залишається питання про роль негативних іонів у біоструктурах. Резонансна природа формування негативних іонів i, що дуже суттєво, саме при малих енергіях, дає підстави вважати, що даний механізм буде спричинювати значні порушення у макромолекулах нуклеїнових кислот. За нашими оцінками, переріз утворення негативних іонів урацилу приблизно у 500 разів менший від перерізу для позитивних іонів. Однак цей факт не є достатньою підставою для висновку про те, що результуючий деструктивний вплив негативних іонів буде меншим, ніж позитивних іонів, оскільки їх реакційні здатності є різними. Крім того, слід мати на увазі, що при великих концентраціях частинок (наприклад, в умовах живої клітини) ймовірність виникнення і стабілізації негативного іона цілої молекули буде зростати.

Важливо також, що із співвідношення (1) випливає, що у клітині низькоенергетичні електрони будуть продукувати, крім негативних іонів урацилу та його складних фрагментів, також атомарний водень. Первинна локалізація атомів водню невідома, але не виключено, що вони можуть відщепитися з С5, С6 піримідинового кільця. В принципі, це можливо, оскільки тут, як показали наші розрахунки, зосереджені області значного позитивного заряду, які й будуть найбільш імовірними місцями первинної атаки електронів.

Стосовно збудження урацилу повільними електронами. Спектр випромінювання урацилу, ініційований електронним ударом у даній області енергій, виникає внаслідок різноманітних процесів. Перше це спектральні переходи між електронно-коливнообертальними станами як цілої молекули урацилу, так і молекулярного іона. Для такої багатоатомної молекули найбільш імовірними будуть лише переходи із нижніх синглетних і триплетних електронних станів у основний стан. Те саме стосується і молекулярного іона. Друге - спектральні переходи між електронно-коливно-обертальними станами фрагмен- 
тів молекули, які утворилися під дією електронного удару (процеси дисоціативного збудження та процеси дисоціативної іонізації зі збудженням).

I накінець, надзвичайно важливо розуміти, що іонізація, фрагментація і збудження молекул нуклеотидних основ навіть при невеликих енергіях електронів приводитимуть до змін первинної та вторинної структур важливих біоінформаційних макромолекул PHК і ДНК. Насамперед слід очікувати дестабілізацію системи водневих зв'язків між комплементарними парами основ, деградацію нуклеотидів, генотоксичні зміни. Внаслідок цього навіть при незначних енергіях впливів у живих клітинах ініціюватимуться незворотні деградаційні та мутагенні процеси.

\section{5. Висновки}

Досліджено процеси іонізації та збудження ізольованих молекул урацилу при їх зіткненнях з низькоенергетичними електронами. Отримано дані про абсолютні величини перерізів утворення негативних і позитивних іонів азотистої основи нуклеїнових кислот урацилу. Показано, що максимальних значень переріз утворення негативних іонів досягає при енергії бомбардуючих електронів $1,1 \mathrm{eB}$, і його абсолютна величина становить $5,0 \cdot 10^{-18} \mathrm{~cm}^{2}$. Визначено абсолютну величину та енергетичну залежність перерізу утворення позитивних іонів для урацилу в інтервалі енергій електронів від порога 9, $4 \pm 0,2$ до $200 \mathrm{eB}$. Максимум перерізу іонізації знаходиться при енергї 95 еВ і дорівнює $(1,0 \pm 0,1) \cdot 10^{-15} \mathrm{~cm}^{2}$. Експериментально встановлено, що електрони з енергіями кілька еВ (нижче енергетичних порогів електронного збудження та позитивної іонізації) ефективно руйнують молекулу урацилу, продукуючи рухливий радикал водню і негативно заряджений фрагмент урацилу.

Взаємодія повільних електронів із молекулами урацилу в газовому стані супроводжується виникненням у діапазоні 200-490 нм емісійного спектра складної форми, що свідчить про інтенсивну фрагментацію молекул. Спектр випромінювання урацилу формують процеси дисоціативного збудження молекул, дисоціативного збудження з іонізацією, збудження електронних рівнів вихідної молекули та молекулярного іона. Отримані дані можуть бути використані для оцінки радіаційних змін у молекулах ДНК і РНК при внутрішньому $\beta$-опроміненні біооб'єктів.

1. М.И. Суховия, И.И. Шафраньош, Механизмы радиаиионного поражения и восстановления нуклеиновых кислот Пущино-на-Оке (1980).
2. М.И. Суховия, В.Н. Славик, И.И. Шафраньош, Л.Л.Шимон, Биополимеры и клетка 7, 77 (1991).

3. M.I. Sukhoviya, M.I. Shafranyosh, and I.I. Shafranyosh, in Spectroscopy of Biological Molecules: New Directions (Kluwer, Dordrecht, 1999), p. 281.

4. V. Cobut, Y. Frongillo, J.P. Patau, T. Goulet, M.J. Fraser, and J.P. Jay-Gerin, Radiat. Phys. Chem. 51, 229 (1998).

5. I.I. Shafranyosh, M.I. Sukhoviya, M.I. Shafranyosh, J. Phys. B 39, 4155 (2006).

6. И.И. Шафраньош, М.І. Суховия, М.И. Шафраньош, Л.Л. Шимон, ЖТФ 78, 127 (2008).

7. И.И Шафраньош, М.И. Суховия, Оптика и спектроскопия 102, 4553 (2007).

8. Л.В. Гурвич, Г.В. Карачевцев, В.Н. Кондратьев, Энергии разрыва химических связей. Потенииаль ионизачии и сродство $к$ электрону (Наука, Москва, 1974).

9. G. Hanel, B. Gstir, S. Denifl et al., Phys. Rev. Lett. 90, 188104 (2003).

10. S. Steenken , J.P. Telo, H.M. Novais, and L.P. Candeias, J. Am. Chem. Soc. 114, 4701 (1992).

11. Р.А. Хмельницкий, Б.П. Терентьев, Успехи химии 48, 854 (1979).

12. А.А. Полякова, Молекуллрный масс-спектральный анализ органических соединений (Химия, Москва, 1993).

13. S. Feil, K. Gluch, S. Matt-Leuber, P. Scheier, J. Limtrakul, M. Probst, H. Deutsh, K. Becker, A. Stamatovic, and T.D. Mark, J. Phys. B 37, 3013 (2004).

14. NIST Standard Reference Database [http://webbook.nist.gov/chemistry]; $\quad$ AIST Spectral Database for Organic Compounds [http://riodb01.ibase.aist.go.jp/sdbs/cgibin/direct_frame_top.cgi]

15. М.I. Шафраньош, Науковий вісник Ужгородського університету. Серія фізика 25, 208 (2009).

16. H. Deutsch, K. Becker, S. Matt, and T.D. Mark, Plasma Phys. Control. Fusion 40, 1721 (1998).

17. H. Deutsch, P. Scheier, S. Matt-Leubner, K. Becker, and T.D. Mark, Int. J. Mass Spectr. 243, 215 (2005).

18. Г. Бете, Квантовая механика, Ганс Альбрехт Бете; пер. с англ. В.П. Скворцова, (Мир, Москва, 1965).

19. Н. Мотт, Г. Месси, Теория атомных столкновений (Мир, Москва, 1969).

20. И.П. Виноградов, В.В. Земских, Н.Я. Додонова, Оптика и спектроскопия 36, 596 (1974).

21. К.-П. Хюбер, Г. Герцберг, Константы двоатомных молекул (Мир, Москва, 1984).

22. Г. Герцберг, Электронные спектры и строение двухатомных молекул (Мир, Москва, 1969). 
23. R.W.Pearse and A.G. Gaydon, The identification of molecular spectra (Chapman, London, 1963).

24. В.В. Скубенич, М.М. Повч, И.П. Запесочный, VII Всесоюзная конференция по физике электронных и атомных столкновений. Тезисы докладов. Ч. 1 (Петрозаводск, 1978), Р. 102.

25. H-W. Johims, M. Schwel, H. Baumgartel, and S. Leach, Chem. Phys. 215, 263 (2005).

Одержано 26.11.11

\section{ИОНИЗАЦИЯ И ВОЗБУЖДЕНИЕ МОЛЕКУЛ УРАЦИЛА ЭЛЕКТРОННЫМ УДАРОМ}

М.И. Суховия, М.И. Шафранъош, М.М. Чаварга, И.И. Шафранъош

$\mathrm{P}$ е $з$ ю м е

Экспериментальным путем получены данные об абсолютных величинах сечений образования положительных и отрицательных ионов азотистого основания нуклеиновых кислот - урацила. Показано, что максимальных значений сечение образования отрицательных ионов достигает при энергии бомбардирующих электронов 1,1 эВ, а его абсолютная величина равна $5,0 \cdot 10^{-18} \mathrm{~cm}^{2}$. Определены абсолютная величина и энергетическая зависимость сечения образования положительных ионов урацила в интервале энергий электронов от порога образования до 200 эВ. Максимум сечения ионизации находится при энергии 95 эВ и равен $(1,0+0,1) \cdot 10^{-15} \mathrm{~cm}^{2}$. Получены спектры люминесценции изолированных молекул урацила в области длин волн 200-500 нм под действием медленных электронов. В спектре наблюдается около 20 спектральных полос и линий. Показано, что спектр излучения урацила формируют процессы диссоциативного возбуждения молекул, диссоциативного возбуждения с ионизацией, возбуждения электронных уровней исходной молекулы и молекулярного иона. Обсуждены биофизические следствия полученных результатов.

\section{ELECTRON IMPACT IONIZATION AND EXCITATION OF URACIL MOLECULES}

\author{
M.I. Sukhoviya, M.I. Shafranyosh, M.M. Chavarga, \\ I.I. Shafranyosh
}

Uzhgorod National University

(54, Voloshin Str., Uzhgorod 88000, Ukraine;

e-mail: ivanshafr@gmail.com)

$\mathrm{S}$ u m m a r y

The cross-sections of the formation of positive and negative ions of uracil, a nitrogenous base of nucleic acids, are obtained experimentally. The values for negative ions were shown to reach their maximum of $5.0 \times 10^{-18} \mathrm{~cm}^{2}$ at an energy of bombarding electrons of $1.1 \mathrm{eV}$. The magnitudes and the energy dependence were determined for the cross-section of formation of positive uracil ions in the electron energy interval from the formation threshold to $200 \mathrm{eV}$. The ionization cross-section peak of $(1.0 \pm 0.1) \times 10^{-15} \mathrm{~cm}^{2}$ was found at an energy of $95 \mathrm{eV}$. The luminescence spectrum for isolated uracil molecules consisting of about 20 spectral bands and lines emitted under the action of slow electrons was obtained in the wavelength range $200-500 \mathrm{~nm}$. The uracil radiation spectrum was shown to be driven by the processes of molecular dissociative excitation, dissociative excitation with ionization, and excitation of electron levels in the initial molecule and the molecular ion. The biophysical consequences of the results obtained are discussed. 